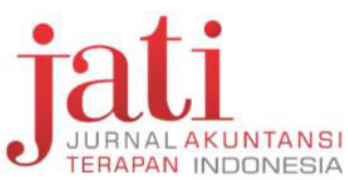

Jati: Jurnal Akuntansi Terapan Indonesia Vol 1 No 1 Hal 38-45 Maret 2018

\title{
Praktik Penerapan Akad Murabahah dalam Pembiayaan Pensiun di Bank Syariah Mandiri
}

\author{
http://journal.umy.ac.id/index.php/jati \\ C)2018 JATI. All rights reserved \\ DOI: 10.18196/jati.010104
}

DATA ARTIKEL:

Diterima: 24 Feb 2018

Direviu: 26 Feb 2018

Direvisi: 10 Mar 2018

Disetujui: 12 Mar 2018

TOPIK ARTIKEL:

Akuntansi Syariah

\begin{abstract}
ABSTRAK: Tujuan dari penelitian ini adalah menyelidiki mekanisme pembiayaan pensiun di Bank Syariah Mandiri dan menyelidiki relevansi akad murabahah mengenai produk pembiayaan pensiun dengan Dewan Fatwa Nasional Syariah (DSN) dari Majelis Ulama Indonesia (MUI) No: 04 / DSN - MUI / IV / 2000 tentang Ketentuan Umum Pembiayaan Murabahah. Penelitian ini dilakukan Objek penelitian ini adalah akad murabahah dalam pembiayaan pensiun. Penelitian ini dilaksanakan di Bank Syariah Mandiri Cabang Wirobrajan. Responden pada penelitian ini yaitu manajer bagian hubungan konsumen perbankan. Penelitian ini menggunakan pendekatan deskriptif kualitatif untuk menganalisis data. Hasil penelitian menunjukkan bahwa mekanisme penyediaan dana pensiun di Bank Syariah Mandiri Wirobrajan dapat dilakukan dengan cara nasabah mengajukan pembiayaan pensiunan beserta kelengkapan berkasnya ke bank, kemudian bank melakukan pengecekan kelengkapan dokumen dan investigasi atas kebenaran data. Jika bank menyetujuinya, nasabah mengisi surat persetujuan pembiayaan dan melaksanakan akad. Penelitian ini juga menemukan bahwa proses akad murabahah dalam produk pembiayaan pensiun relevan dengan fatwa Dewan Syariah Nasional (DSN) Majelis Ulama Indonesia (MUI) No: 04/ DSNMUI/IV/2000, mengenai ketentuan umum pembiayaan murabahah.
\end{abstract}

Kata Kunci: Pensiun; Pembiayaan; Syariah; Murabahah
ABSTRACT: The objectives of this research are investigate the mechanism of pension funding in Syariah Mandiri Bank and investigate the relevance of murabahah agreement on financing product of pension with National Shari'a Council Fatwa (DSN) of the Indonesian Ulema Council (MUI) No: 04 / DSN - MUI / IV / 2000, concerning general provisions of murabahah financing. The object of this research is murabahah agreement of pension funding. This reseach conducted in Syariah Mandiri Bank Branch of Wirobrajan. The respondent of this research is consumer banking relationship manager. This research used descriptive-qualitative to analize the data. The result of the study shows that the mechanism of providing pension financing in Syariah Mandiri Bank on Wirobrajan are the customers apply pension funding along with the com-pleteness of the file to the bank, then the bank to check the completeness of documents and investigation of the truth data. If the bank approves it, the customer fills out the approval of the financing and executes the contract. Another findings in this research are The process of murabahah contract in pension financing product is relevance with the National Shari'a Council Fatwa (DSN) of the Indonesian Ulema Council (MUI) No: 04 / DSN - MUI / IV / 2000, regarding general provisions for murabahah financing.

\section{Keywords: Pension; Funding; Shari'a; Murabahah}

\section{SITASI ARTIKEL:}

Wulaningrum, P. D., \& Nisa, A. (2018). Praktik Penerapan Akad Murabahah dalam Pembiayaan Pensiun di Bank Syariah Mandiri. Jati: Jurnal Akuntansi Terapan Indonesia, 1(1), 38-45.

\section{PENDAHULUAN}

Perkembangan perbankan syariah di Indonesia beberapa tahun terakhir mengalami peningkatan yang signifikan. Laporan Perkembangan Keuangan Syariah yang diterbitkan oleh OJK tahun 2016 menunjukkan bahwa Pertumbuhan aset, PYD dan DPK industri perbankan syariah 
nasional di tahun 2016 yang terdiri dari Bank Umum Syariah (BUS), Unit Usaha Syariah (UUS) dan Bank Pembiayaan Rakyat Syariah (BPRS) masing-masing mengalami pertumbuhan sebesar 20,28\%, 16,41\% dan 20,84\%. Hal ini menandakan kepercayaan masyarakat meningkat terhadap operasional perbankan syariah.

Kepercayaan masyarakat tentunya tidak lepas dari daya tarik sistem keuangan Islam yang berlandaskan pada prinsip-prinsip moral yang mengutamakan keadilan, perdagangan yang adil, kesamaan, dan etika yang bertujuan untuk menciptakan lingkungan yang sehat dan sportif (Khan, 2011). Keunggulan ini tercermin dalam prinsip utama perbankan syariah yang bebas riba dan menerapkan sistem bagi hasil.

Riba berarti pendapatan diterima lebih dari nilai dasar atau nilai sebenarnya baik dalam pinjaman atau pertukaran komoditas yang berdampak pada ketidakadilan bahkan eksploitasi bagi orang-orang yang membutuhkan dana (Khan, 2011). Riba ini diterapkan pada bank konvensional dalam bentuk bunga. Sedangkan pada bank syariah, sistem bunga dihapuskan dan diganti menjadi sistem bagi hasil. Sistem bagi hasil dirasa lebih adil bagi seluruh kalangan masyarakat baik bagi pemilik kelebihan dana maupun bagi yang membutuhkan dana. Prinsip inilah yang selalu dijadikan sebagai landasan perbankan syariah mengembangkan produk-produknya.

Produk perbankan syariah dengan sistem bagi hasil dapat berhubungan dengan usaha pengumpulan dana (funding) maupun penyaluran dana /pembiayaan (financing) (Zaenudin, 2014). Salah satu produk pembiayaan berbasis syariah yang cukup banyak diminati adalah produk jual beli dengan akad murabahah. Murabahah merupakan akad jual beli komoditas tertentu dengan cara penjual menjelaskan kepada pembeli tentang harga jual yang terdiri dari harga perolehan dan margin (keuntungan) yang diambil penjual kemudian pembeli menyetujui harga jual tersebut (Hakim, 2012). Konsep murabahah secara sederhana merupakan bentuk jual beli yang ditambah dengan komisi atau suatu bentuk penjualan barang dengan harga awal barang ditambahkan dengan keuntungan sesuai dengan kesepakatan (Pratiwi \& Septiarini, 2014).

Konsep dan aplikasi pembiayaan dengan akad Murabahah yang sederhana dan memudahkan penanganan administrasi bank syariah merupakan faktor utama bank Syariah di Indonesia lebih banyak menerapkan prinsip murabahah dalam pembiayaan. Hal ini dikarenakan praktik murabahah menggunakan sistem cicilan berkala (installment) sehingga dapat disesuaikan dengan kemampuan pembayaran nasabah. Selain itu, adanya regulasi tentang pembiayaan murabahah yaitu Fatwa Dewan Syariah Nasional (DSN) Majelis Ulama Indonesia (MUI) No: 04 / DSN - MUI / IV / 2000 tentang ketentuan umum pembiayaan murabahah dalam bank syariah dan PSAK 102 Revisi 2013 tentang akuntansi murabahah yang menjadi landasan pelaksanaan pembiayaan murabahah dan panduan pengakuan, pencatatan, pengukuran, penyajian serta pengungkapan dalam transaksi pembiayaan murabahah menjadi penguat bagi bank maupun bagi masyarakat untuk memanfaatkan produk perbankan syariah berbasis murabahah.

Produk pembiayaan murabahah yang mulai berkembang saat ini sangat beragam, salah satunya adalah pembiayaan pensiun. Program pensiun di beberapa negara maju berfungsi sebagai jaminan untuk pendapatan minimum di masa depan (Bikker, Steenbeek, \& Torracchi, 2012). Di Indonesia sendiri, keberadaan program pensiun ini bertujuan untuk mengelola penyisihan pendapatan karyawan selama masa kerja mereka sebagai investasi masa depan. Ketika karyawan telah selesai masa kerja atau tidak dapat menghasilkan pendapatan lagi, karyawan atau ahli warisnya tersebut akan menerima pembayaran berkala selama masa hidupnya yang disebut sebagai manfaat pensiun (Nussy, 2014). Oleh karena itu, Pembiayaan pensiun menjadi salah satu pembiayaan yang potensial meningkatkan perekonomian mandiri masyarakat bahkan ketika masyarakat sudah tidak berada di usia produktif lagi.

Program pensiun bagi pegawai negeri diatur dalam UU No.43 Tahun 1999 Pasal 10 yang menyatakan bahwa pensiun adalah jaminan hari tua dan sebagai penghargaan terhadap Pegawai Negeri yang telah bertahun-tahun mengabdikan dirinya kepada Negara. Sedangkan bagi karyawan non pegawai negeri, pensiun di atur dalam UU no.11 tahun 1992. Para pensiun yang ingin memanfaatkan dana pensiun untuk kelangsungan hidupnya setelah tidak bekerja sebagai pegawai, baik sebagai modal usaha maupun kebutuhan lainnya, membutuhkan lembaga penghimpun dan penyalur dana agar kebutuhannya terpenuhi.

Kebutuhan untuk menghimpun dan menyalurkan dana pensiun ini merupakan potensi yang mulai ditangkap oleh beberapa bank syariah di Indonesia, salah satunya adalah Bank Syariah Mandiri. Bank Syariah Mandiri saat ini sudah memiliki produk pembiayaan pensiun. Agar pembiayaan pensiun sesuai dengan ketentuan Islam, Bank Syariah Mandiri (BSM) memadukan pembiayaan pensiun dengan basis murabahah. 
Bank Syariah Mandiri selama ini menunjukkan partumbuhan yang cukup besar dalam hal pembiayaan dan aset-aset kepemilikannya (Purnamasari, 2015). Khusus untuk pembiayaan pensiun berbasis murabahah, Bank Syariah Mandiri pada tahun 2016 mencapai Rp 1,44 triliun yang menandakan partumbuhan sebanyak 165\%. Adapun sampai Desember, Jumlah pensiunan yang melakukan penyaluran pensiunan mencapai 13.447 orang atau 130\% dibandingkan tahun 2015 yang hanya 5.854 (www.syariahfinance.com, 2016). Hal ini menunjukkan bahwa tingkat kepercayaan masyarakat akan produk pembiayaan pensiun berbasis murabahah dari Bank Syariah Mandiri semakin meningkat.

Penelitian terdahulu telah meneliti tentang akad murabahah dari beberapa aspek, salah satunya penelitian dari Shaikh (2011) yang membandingkan praktik murabahah pada bank syariah dengan praktik pinjaman dari bank konvensional. Hasil analisisnya menunjukkan bahwa praktik murabahah menawarkan alternatif yang lebih baik dibandingkan pinjaman konvensional karena perbedaan struktur dan kontrak hukumnya. Namun belum banyak penelitian studi kasus tentang praktik penerapan murabahah di bank syariah. Penelitian dari Shaikh (2011) juga baru membahas aspek murabahah saja, belum melihat kesesuaian penerapan akad murabahah di lapangan terhadap Fatwa Dewan Syariah Nasional (DSN) Majelis Ulama Indonesia (MUI) No: 04 / DSN - MUI / IV / 2000 tentang ketentuan umum pembiayaan murabahah dalam bank syariah. Disamping itu, studi kasus tentang praktik penerapan akad murabahah dalam pembiayaan pensiun juga masih belum diteliti.

Berdasarkan penelitian Shaikh (2011) dan keterbatasan penelitian sebelumnya, peneliti tertarik untuk menganalisis kesesuaian penerapan akad murabahah terhadap Fatwa Dewan Syariah Nasional (DSN) Majelis Ulama Indonesia (MUI) No: 04/DSN-MUI/IV/2000 dalam produk pembiayaan pensiun Bank Syariah Mandiri Cabang Wirobrajan.
Bank Syariah Mandiri menerapkan sistem dan menawarkan produk pembiayaan berbasis syariah yang sama di seluruh kantor cabangnya. Oleh karena itu, seluruh kantor cabang bank syariah mandiri di Indonesia memiliki fitur-fitur yang serupa dalam penerapan dan produknya, termasuk Bank Syariah Mandiri Cabang Wirobrajan. Bank Syariah Mandiri Cabang Wirobrajan merupakan satu dari 19 kantor cabang di Yogyakarta. Bank Syariah Mandiri Cabang Wirobrajan dipilih karena kantor cabang ini termasuk kantor cabang Bank Syariah Mandiri golongan awal yang didirikan di Yogyakarta sehingga produk-produk yang ditawarkan sudah lebih lengkap dan lebih lama diterapkan. Produk pembiayaan pensiunpun sudah lama menjadi produk pembiayaan berbasis murabahah unggulan dari Bank Syariah Mandiri Cabang Wirobrajan. Di samping itu, karena Bank Syariah Mandiri Cabang Wirobrajan sudah lama berdiri, maka sudah banyak pula nasabah yang mempercayakan dananya kepada Bank Syariah Mandiri Cabang Wirobrajan. Penelitian ini bertujuan untuk mengetahui mekanisme produk pembiayaan pensiunan di BSM Cabang Wirobrajan dan mengetahui kesesuaian penerapan akad murabahah pada produk pembiayaan pensiunan dengan Fatwa Dewan Syariah Nasional (DSN) Majelis Ulama Indonesia (MUI) No: 04/DSNMUI/IV/2000 tentang ketentuan umum pembiayaan murabahah.

Secara teoritis, penelitian ini bertujuan untuk menambah wawasan ilmu manajemen keuangan syariah khususnya mengenai akad murabahah dan pembiayaan pensiun. Selain itu, secara praktis penelitian ini memberikan bukti tentang praktik penerapan akad murabahah dalam pembiayaan pensiun sehingga penelitian ini secara praktis dapat berkontribusi bagi pihak bank maupun nasabah sebagai bahan evaluasi penerapan praktik syari'ah yang efektif dan sesuai dengan fatwa DSN MUI No: 04/DSN-MUI/IV/2000. Kerangka konseptual penelitian ini tersaji dalam Gambar 1.

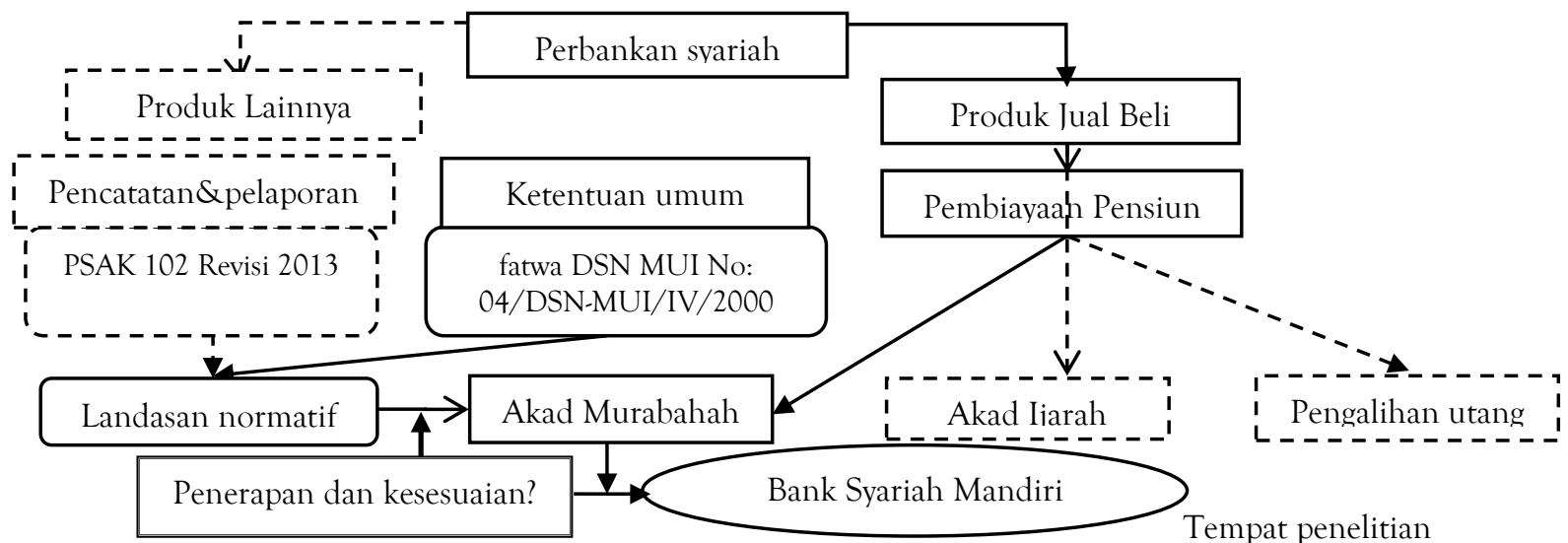

Gambar 1. Kerangka Konseptual Penelitian 


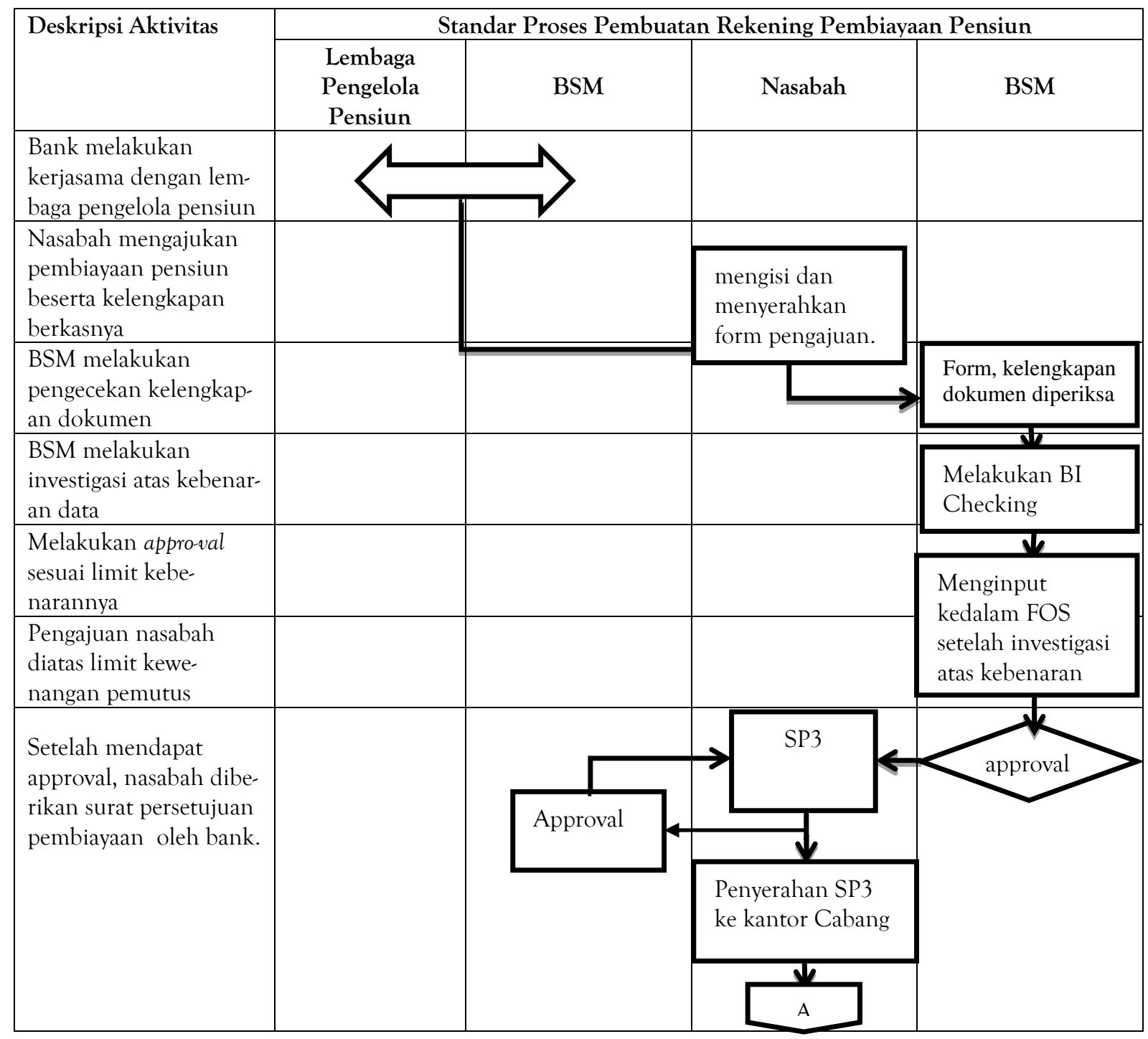

Gambar 2. Bagan Alir Standar Proses Pembuatan Rekening Pembiayaan Pensiun

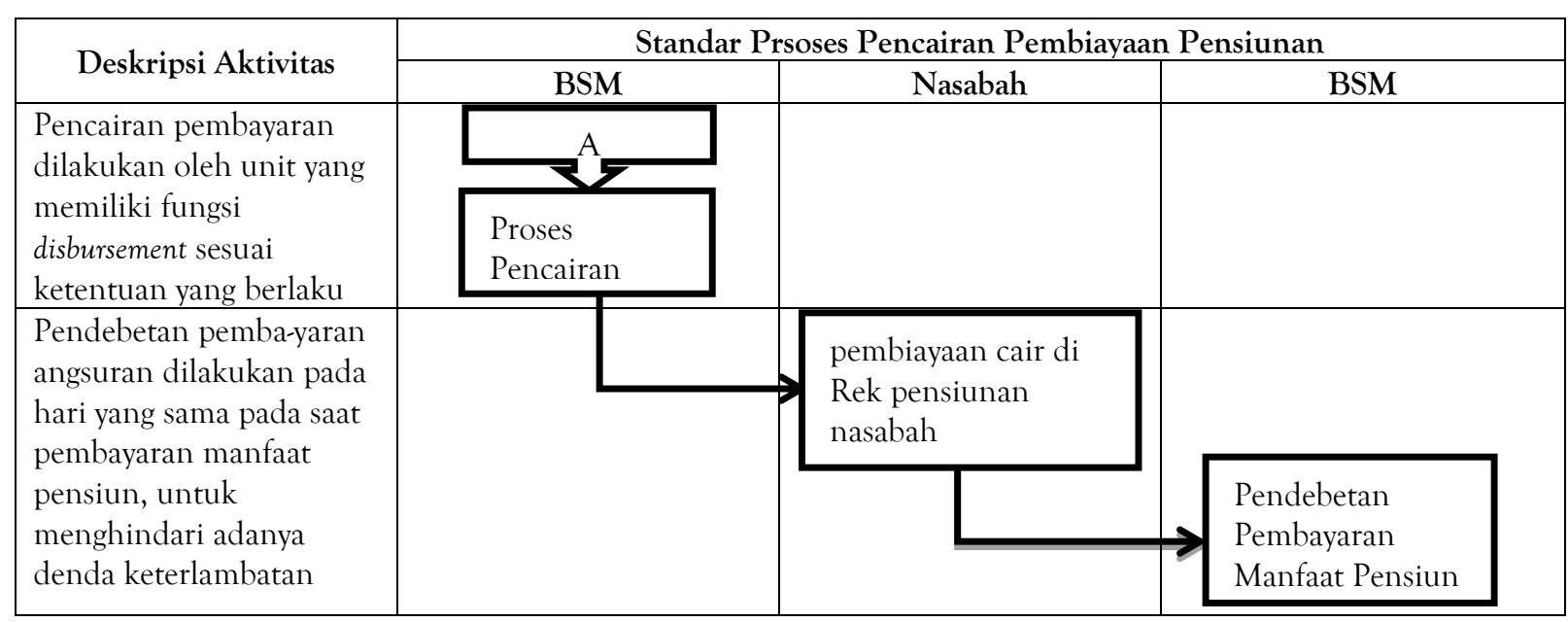

Gambar 3. Bagan Alir Standar Proses Pencairan Pembiayaan Pensiunan 


\section{METODE PENELITIAN}

Penelitian ini menggunakan studi kasus untuk mekanisme pembiayaan pensiun dan menganalisis penerapan akad murabahah pada produk pembiayaan pensiun. Penelitian ini dilaksanakan di Bank Syariah Mandiri (BSM) Kantor Cabang Wirobrajan Yogyakarta yang beralamat di Jl. HOS Cokroaminoto no. 33 A Yogyakarta. Obyek yang diteliti dalam penelitian ini adalah akad murabahah dalam pembiayaan pensiun.

Data yang digunakan adalah data primer dan data sekunder. Teknik pengumpulan data primer dengan menggunakan wawancara kepada Manajer Bagian Hubungan Konsumen Perbankan Bank Syariah Mandiri Cabang Wirobrajan yang mengelola pembiayaan pensiun. Pengumpulan data sekunder dilakukan dengan observasi ke BSM cabang Wirobrajan agar data yang diperoleh akurat serta mengumpulkan dokumen-dokumen yang berisi tentang sistem akad murabahah dan pembiayaan pensiun dari BSM Cabang Wirobrajan yang diperlukan selama proses observasi. Jenis data pada penelitian ini berupa data kualitatif. Penelitian ini menggunakan teknik analisis data metode deskriptif kualitatif dengan penulis terlebih dahulu akan melakukan pengumpulan data-data terkait pene-rapan akad murabahah pada pembiayaan pensiun kemudian akan dilakukan klarifikasi, analisis, dan selanjutnya akan diinterpretasi atau disajikan secara sistematis dan akurat, sehingga akan memberikan gambaran yang jelas tentang praktik penerapan akad murabahah dalam pembiayaan pensiun di BSM Cabang Wirobrajan.

\section{HASIL DAN PEMBAHASAN}

\section{Mekanisme Pembiayaan Pensiun}

Pembiayaan pensiun di Bank Syariah Mandiri cabang Wirobrajan merupakan salah satu jenis pembiayaan konsumen. Pembiayaan segmen ini menjadi salah satu bidang bisnis BSM yang dikembangkan dan dipasarkan dengan tujuan memenuhi kebutuhan masyarakat. Produk pembiayaan pensiun merupakan pembiayaan yang diberikan kepada para pensiunan. Pensiunan yang dimaksud adalah penerima manfaat pensiun yang berasal dari Aparatur Sipil Negara Pusat, Aparatur Sipil Negara Daerah, TNI POLRI, pegawai BUMN/BUMD dan sudah memiliki SK pensiun baik yang belum maupun sudah masuk terhitung mulai tanggal pensiun.

Skema pembiayaan pensiunan pada Bank Syariah Mandiri (BSM) antara lain pembiayaan dengan skema jual-beli (murabahah), sewa (ijarah), atau pengalihan utang / take over (Qardh Wal Murabahah / Qardh Wal ljarah / Musyarakah Mutanaqisah / Ijarah Muntahiya Bit Tamlik). Pembiayaan tersebut diberikan kepada penerima manfaat pensiun bulanan melalui BSM sebagai kantor bayar. Limit pembiayaan maksimal Rp 350.000.000,00 atau disesuaikan dengan batas maksimal DSR nasabah dan usia pemohon dengan jangka waktu pembayaran maksimal 15 tahun. Usia minimal pengajuan pembiayaan untuk pensiunan yaitu 50 tahun kecuali pensiunan janda yaitu dengan batas minimal 48 tahun. Sedangkan usia maksimal nasabah saat jatuh tempo pembayaran adalah 75 tahun. Jaminan pembiayaan yang disyaratkan oleh BSM cukup mudah yaitu apabila pensiunan maka menyertakan SK Pensiuan asli, sedangkan jika pensiunan janda perlu menyertakan SK Pensiunan Terusan / Otomatis / Janda Asli. Jumlah Debt Service Ratio (DSR) pensiunan dan pensiunan janda maksimal 70\% dari manfaat pensiunan bulanan.

Pada pembiayaan pensiunan di Bank Syariah Mandiri (BSM), bank bertindak sebagai penyalur dari pengelola dana pensiun (dalam hal ini TASPEN) kepada penerima manfaat pensiun (PMP). BSM telah bermitra dengan pengelola dana pensiun, dalam hal ini TASPEN. Apabila para pensiunan ingin mendapatkan produk pembiayaan pensiun melalui BSM, maka syaratnya adalah para pensiunan sudah melakukan iuran pensiun ke pengelola dana pensiun (TASPEN). Saat pensiunan mengajukan pembiayaan kepada pihak bank, maka pihak BSM akan menyalurkan dana dari TASPEN kepada pensiunan.

Mekanisme proses pembiayaan pensiunan dimulai dari dijalinnya kerja sama antara pihak bank dengan pihak pengelola dana pensiun yaitu TASPEN. Nasabah yang memiliki dana pensiun di TASPEN apabila ingin mengajukan pembiayaan pensiun di BSM perlu mengisi dan mengajukan form pengajuan pembiayaan pensiun. Selanjutnya BSM melakukan pengecekan kelengkapan dokumen pengajuan. Tahapan setelahnya adalah BSM melakukan investigasi atas kebenaran data dengan melakukan BI checking. Saat BI checking dinilai berhasil, bank melakukan approval sesuai limit kebenarannya. Approval dilakukan dengan menginput ke dalam FOS setelah investigasi atas kebenaran. Langkah yang sama juga dilakukan ketika terdapat pengajuan nasabah di atas limit kewenangan pemutus. Setelah mendapat approval, nasabah diberikan surat persetujuan pembiayaan (SP3) oleh bank untuk diisi. Setelah nasabah menyerahkan kembali SP3 yang telah diisi ke pihak BSM, BSM selanjutnya membuatkan renening untuk nasabah dan proses pembuatan rekening pembiayaan pensiun pun telah selesai. Gambar 2 
menunjukkan bagan alur mekanisme proses pembiayaan pensiun ini.

Apabila nasabah sudah memiliki rekening pembiayaan pensiun, maka nasabah juga sudah dapat melakukan pencairan untuk pembiayaan pensiun. Proses pencairan pembayaran di BSM dilakukan oleh unit yang memiliki fungsi disbursement sesuai ketentuan yang berlaku. Pada saat pembayaran manfaat pensiun diberikan atau dengan kata lain pembiayaan pensiun dicairkan dari rekening nasabah, pendebetan pembayaran angsuran dilakukan pada hari yang sama agar meminimalisir adanya denda keterlambatan. Bagan alur pencairan pembiayaan pensiunan di BSM tergambarkan gambar 3 .

\section{Analisis Penerapan Akad Murabahah dalam Pembiayaan Pensiun}

Para pensiun merupakan pasar potensial dalam mendukung pertumbuhan pembiayaan konsumen Bank Syariah Mandiri, mengingat jumlah pegawai negeri maupun swasta yang sudah pensiun tiap tahun mengalami peningkatan. Potensi yang dinilai cukup besar tersebut didukung Dewan Syariah Nasional dengan aturan terkait pembiayaan pensiunan yang tercantum dalam Fatwa Dewan Syariah Nasional (DSN) Majelis Ulama Indonesia (MUI) No: 04/DSN-MUI/IV/2000, tentang ketentuan umum pembiayaan murabahah.

Fatwa DSNMUI No: 04/DSN-MUI/IV/2000 berisi 9 ketentuan umum pembiayaan murabahah sebagai landasan bank-bank syariah menerapkan prinsipprinsip murabahah. Fatwa tersebut antara lain: (1) Bank dan nasabah harus melakukan akad murabahah yang bebas riba; (2) Komoditas yang diperjualbelikan tidak dilarang oleh syari'at Islam; (3) Bank diperbolehkan membayar sebagian atau seluruh harga pembelian komoditas yang telah disepakati kualifikasinya; (4) Bank membeli barang yang di pesan nasabah atas nama bank sendiri dan harus sah dan bebas riba; (5) Penjual (bank) diwajibkan menjelaskan seluruh hal yang berhubungan dengan pembelian komoditas; (6) Bank menjual barang tersebut kepada nasabah (pemesan) dengan harga jual senilai harga perolehan ditambah keuntungannya; (7) Pemesan (nasabah) berkewajiban melakukan pembayaran harga barang sesuai dengan jangka waktu yang telah disetujui; (8) Mencegah adanya cedera janji dan penyalahgunaan akad; (9) Jika bank memberi kuasa nasabah untuk membeli barang kepada pihak pemasok, maka akad murabahah harus dilaksanakan setelah komoditas secara prinsip milik bank.
Kesesuaian praktik akad murabahah untuk pembiayaan dana pensiun dengan ketetapan DSN MUI dalam penelitian ini dianalisis dari kasus nasabah pembiayaan pensiun yang ingin mengajukan pembiayaan untuk renovasi rumah. Pertamatama, BSM menjelaskan kepada pemohon terkait akad murabahah, tujuan pembiayaan, harga perolehan, harga jual, margin dan angsuran, hal ini sesuai dengan ketentuan pertama dari DSN MUI. Praktik selanjutnya, Bank menjelaskan tentang objek pembelian menggunakan akad murabahah. Pada kasus untuk renovasi rumah, bank memberikan pembiayaan untuk membeli bahan baku dalam merenovasi rumah. Praktik ini juga sudah sejalan dengan fatwa DSN MUI tentang akad murabahah yang kedua.

Proses selanjutnya adalah bank mewakilkan nasabah untuk membeli barang tersebut kemudian pemasok menyerahkan barang kepada nasabah dengan sepengetahuan dan sepertujuan dari bank. Proses ini terkait dengan fatwa DSN MUI pada bagian ketiga dan keempat mengenai prosedur pembelian barang. Tahap lain setelah barang sudah diterima pembeli (nasabah), Bank menjelaskan terkait jatuh tempo angsuran setiap bulannya, menjelaskan biaya-biaya yang timbul terkait pencairan pembiayaan seperti biaya administrasi, biaya materai, Bank juga menjelaskan kepada nasabah terkait agunan dalam pembiayaan pensiun. Tahap ini sama dengan fatwa DSN MUI yang keenam. Selanjutnya, Bank menjelaskan kewajiban nasabah, seperti melakukan pembayaran tempat waktu, Bank menjelaskan terkait cedera janji apabila nasabah tidak melakukan pembayaran. Hal ini menunjukkan kesamaan praktik dengan fatwa DSN MUI nomor 7 sampai 9 .

Contoh kasus pembiayaan renovasi rumah tersebut memberikan gambaran bahwa praktik di BSM telah sesuai dengan fatwa MUI. Analisis kesesuaian Fatwa DSN MUI tentang akad murabahah secara lengkap berdasarkan dokumen dari BSM serta wawancara terhadap responden dapat dilihat dalam pembiayaan pensiun tersaji dalam Tabel 1. Praktik akad murabahah di BSM ini sejalan dengan hasil temuan penelitian dari Shaikh (2011) mengenai prinsip-prinsip pelaksanaan akad murabahah yang menerapkan kontrak dan perjanjian hukum yang jelas berdasarkan kesepakatan bersama. Penelitian ini sekaligus menyempurnakan penelitian dari Shaikh (2011) dengan membandingkan praktik akad murabahah yang dikhususkan pada pembiayaan pensiun terhadap peraturan DSN MUI sehingga penelitian ini memberikan bukti nyata dari studi kasus penerapan akad murabahah khususnya di Indonesia. 
Tabel 1. Analisis Kesesuaian Fatwa DSN MUI tentang Akad Murabahah dengan Pembiayaan Pensiun BSM Cabang Wirobrajan

No $\quad$ Fatwa DSN MUI No: 04/DSN- $\quad$ Pembiayaan Pensiun BSM cabang Wirobrajan $\quad$ Sesuai
$\mathrm{MUI} / \mathrm{IV} / 2000$

Pembiayaan Pensiun BSM cabang Wirobrajan

/ Tidak

Sesuai

Sesuai

1. Bank dan nasabah harus melakukan akad murabahah yang bebas riba (memenuhi rukun-rukun atau syarat akad yaitu penjual dan pembeli, objek murabahah dan ijab qabul)

2. Komoditas yang diperjualbelikan tidak dilarang oleh syari'at Islam

3. Bank diperbolehkan membayar sebagian atau seluruh harga pembelian komoditas yang telah disepakati kualifikasinya

4. Bank membeli barang yang di pesan nasabah atas nama bank sendiri, dan pembelian ini harus sah dan bebas riba

5. Penjual (bank) diwajibkan menjelaskan seluruh hal yang berhubungan dengan pembelian komoditas, contohnya apabila pembelian dilakukan secara utang

6. Bank menjual barang tersebut kepada nasabah (pemesan) dengan harga jual senilai harga perolehan ditambah keuntungannya. Bank ha-rus menjelaskan secara jujur harga pokok barang kepada nasabah beri-kut biaya yang dikeluarkan

7. Pemesan (nasabah) berkewajiban melakukan pembayaran harga barang sesuai dengan jangka waktu yang telah disetujui

8. Mencegah adanya cedera janji dan penyalahgunaan akad, kedua belah pihak dapat membuat perjanjian khusus

9. Apabila bank memberi kuasa nasabah untuk membeli barang kepada pihak pemasok, maka akad murabahah harus dilaksanakan setelah komoditas secara prinsip milik bank
Pada saat proses akad pembiayaan pensiunan, nasabah wajib hadir berhadapan dengan pihak bank. Penandatangan akad wajib dilakukan oleh pemohon (nasabah) dan disaksikan oleh pasangan nasabah/wali. Objek yang disediakan bank adalah memfasilitasi nasabah untuk membeli komoditas tertentu sesuai tujuan nasabah serta tidak bertentangan dengan prinsip syariah.

Pembiayaan yang diperbolehkan nasabah dalam pembiayaan pensiunan adalah pembiayaan untuk pembelian atau renovasi rumah, pembelian barang untuk usaha, pembelian peralatan atau kebutuhan rumah tangga, pembelian kendaraan bermotor dan lain-lain.

Bank memproses dan memverifikasi kelengkapan data nasabah serta menen-tukan maksimal pembiayaan yang disesuaikan dengan batas maksimal DSR nasabah dan usia pemohon. Jika keduanya sepakat, maka dapat ditindak lanjuti dengan pembuatan kontrak jual beli.

"Nasabah membeli sendiri barang yang dinginkan ke kuasa, dimana surat tersebut menjelaskan bahwa bank memberikan kuasa kepada nasabah (mewakilkan) untuk membeli barang atas nama bank."[R1]

Penjelasan terkait pembelian (objek mura-bahah), pembayaran, telah tercantum secara detail di surat perjanjian (akad) secara tertulis. Walaupun demikian bank tetap menyampai-kannya secara langsung kepada nasabah.

"Beberapa hal yang dijelaskan saat akad diantaranya terkait akad murabahah (definisi perjanjian pembiayaan murababah, harga beli, margin, angsuran, biaya-biaya yang timbul), agunan, kewajiban nasabah, dan jedera janji apabila nasabah tidak melakukan pemba-yaran,"[R1]

Pembayaran pembiayaan pensiunan dilakukan secara angsuran (terdiri dari angsuran pokok dan margin/ujrah) yang dibayar melalui pemotongan manfaat pensiun setiap bulannya langsung dari rekening pensiun BSM nasabah dalam jangka waktu yang telah disepakati (maksimal 15 tahun).

Bank melakukan pembuatan perjanjian khusus disesuaikan dengan kebutuhan kedua belah pihak (bank dan nasabah)

BSM meberikan kuasa nasabah untuk membeli barang yang diinginkan atas nama BSM menggunakan pembiayaan yang disediakan oleh bank yang dibuktikan dengan pemberian surat kuasa. Pemasok (pihak ketiga) sesuai dengan yang ditunjuk atau setidaknya disetujui bank. Pemasok menyerahkan barang kepada nasabah dengan sepertujuan bank. pemasok atas nama bank yang dibuktikan dengan surat

\section{SIMPULAN}

Penelitian ini menyimpulkan bahwa mekanisme pembiayaan kepada pensiunan di Bank Syariah Mandiri Cabang Wirobrajan dapat dilakukan dengan cara nasabah yang mengajukan pembiayaan pensiunan beserta kelengkapan berkasnya ke bank, kemudian bank melakukan pengecekan kelengkapan dokumen dan investigasi atas kebenaran data. Jika disetujui bank, nasabah diberikan surat persetujuan pembiayaan dan melaksanakan akad. Pencairan dilakukan setelah nasabah memberitahu 
kepada pemberi kerja (PT TASPEN) terkait pemindahan penyaluran manfaat pensiunan melalui Bank Syariah Mandiri (apabila penyaluran manfaat pensiun melalui bank lain). Penelitian ini juga menemukan bukti bahwa penerapan akad murabahah dalam pembiayaan pensiun di Bank Syariah Mandiri Cabang Wirobrajan telah sesuai dengan 9 ketentuan penerapan akad murabahah dari Fatwa DSN MUI No: 04/DSN-MUI/IV/2000 tentang ketentuan umum pembiayaan murabahah.

Secara teori, penelitian ini memperkaya ilmu manajemen keuangan syariah khususnya mengenai penerapan prinsip syari'ah yang berkaitan dengan akad murabahah dan pembiayaan pensiun. Secara praktik penelitian ini berkontribusi baik bagi pihak perbankan maupun bagi nasabah sebagai bahan evaluasi penerapan praktik syari'ah yang efektif dan sesuai dengan fatwa DSN MUI. Keterbatasan pada penelitian ini adalah penelitian hanya menggunakan fatwa DSN MUI sebagai landasan normatif kesesuaian pelaksanaan praktik murabahah dan tidak melibatkan akademisi atau pakar dari ahli fiqih dan muamalah. Saran bagi penelitian selanjutnya agar melengkapi analisis data penelitian dengan melibatkan para akademisi dan pakar di bidang fiqih dan muamalah.

\section{DAFTAR PUSTAKA}

Fatwa Dewan Syariah Nasional (DSN) Majelis Ulama Indonesia (MUI) No. 04 / DSN - MUI / VII / 2000 tentang Pembiayaan Murabahah

Bikker, J. A., Steenbeek, O. W., \& Torracchi, F. (2012). The Impact of Scale , Complexity , and Service Quality on the Administrative Costs of Pension Funds: A Cross-Country Comparison. The Journal of Risk and Insurance, 79(2), 477-514. https://doi.org/10.1111/j.1539. 6975.2011.01439.x

Hakim, L. (2012). Prinsip Prinsip Ekonomi Islam. Yogyakarta: Erlangga.

http://www.syariahfinance.com/perbankan/664-bsmgencar-pasarkan-produk-pembiayaanpensiun.html, (diakses tanggal 28 maret 2017)

Khan, M. (2011). Islamic Banking Practices: Islamic Law and Prohibition of Ribā. Islamic Studies, 50(3-4), 413-422.

Nussy, A. F. . (2014). Analisis Penerapan PSAK No.18 Mengenai Akuntansi Dana Pensiun pada PT. Taspen Cabang Manado. Jurnal EMBA, 2(4), 444-453.

Otoritas Jasa Keuangan. (2016). Laporan Perkembangan Keuangan Syariah 2016. Jakarta:OJK

Pratiwi, I. E., \& Septiarini, D. F. (2014). Artikel diterima: 15 Juni 2014 Terakhir direvisi: 18
Agustus 2014. AKRUAL Jurnal Akuntansi, 6(1), $17-32$.

Purnamasari, I. (2015). Analisis Akad Mudharabah Dalam Fasilitas Pendanaan Jangka Pendek Syariah Pada Bank Syariah Mandiri. Jurnal Ekonomi Dan Bisnis Islam Al-Tijary, 1(1), 67-72.

Shaikh, M. A. (2011). Contemporary Islamic Banking: The Issue of Murābaḥah. Islamic Studies, 25(3), 435-448.

Undang-Undang No. 43 Tahun 1999 tentang Pokok Kepegawaian.

Zaenudin. (2014). Pengaruh Pendapatan Bagi Hasil Mudharabah, Musyarakah Dan Murabahah Terhadap Bagi Hasil Tabungan (Studi Pada Ksu Bmt Taman Surga Jakarta). Jurnal Etikonomi, 13(1), 69-88. 